\title{
APPCC Na Colheita e Pós-Colheita de Amendoim
}

\section{Teresa Cristina Castilho Gorayeb (I), Juliana Takemoto Arakaki (I), Giulliana Tornelli Lucas (II), João Cláudio Thoméo (I)}

(I) UNESP - IBILCE - Universidade Estadual Paulista - Instituto de Biociências, L (Rua Cristóvão Colombo 2265, 15054-000 São José do Rio Preto, São Paulo, Brasil), (II) FATEC Faculdade de Tecnologia de São José do rio Preto (Rua Fernandópolis, 2510 Eldorado - São José do Rio Preto - SP, Brasil. CEP)

\section{Resumo}

Os problemas com o cultivo do amendoim estão concentrados na colheita porque a maior parte da safra é colhida na época das chuvas. No armazenamento do amendoim, o que dificulta é a secagem das vagens de grãos até os índices exigidos para se obter a segurança do controle de infestações fúgicas evitando-se assim o aumento de aflatoxinas. O objetivo deste trabalho foi identificar as condições mais favoráveis à infestação fúngica e ocorrência da micotoxina e propor um plano de Análise de Perigos e Pontos Críticos de Controle (APPCC) que englobe a colheita e beneficiamento do amendoim. Foram sorteados, aleatoriamente, nove lotes provenientes de plantio no raio de $100 \mathrm{~km}$ da sede de uma empresa de beneficiamento no estado de São Paulo, sendo três em cada safra de 2011/2012, 2012/2013 e 2013/2014 em locais diferentes. Para as amostragens na plantação de amendoim nas etapas de arranque, após secagem ao sol, foram utilizadas as normas da legislação RDC 274 de 2002, ANVISA - Ministério da Saúde - MS, sendo coletados $5 \mathrm{~kg}$ de amostras/ha, em subamostras de 200 gramas, sendo as 25 posições equidistantes em um hectare e percorridas em zig zag. As amostras coletadas na colheitadeira, na carreta na recepção da agroindústria de beneficiamento, na carreta após a secagem e no armazenamento foram coletadas $5 \mathrm{~kg}$ de com o auxilio de amostradores em três pontos, estas foram mantidas em refrigeração em câmara fria e realizado as análises de Unidades Formadoras de Colônia (UFC/g) e de umidade. Observaram-se os 
principais pontos críticos de controle (PCC) na etapa do arranque, a análise do grau de maturação e umidade dos grãos é importante para atingir a maior produtividade, na secagem ao sol o cuidado com os índices pluviométricos e o controle de umidade dos grãos é importantíssimo pois estes devem ser menores de $18 \%$, na colheita mecânica a manutenção preventiva é um procedimento obrigatório.Na recepção é avaliado umidade, o índice de impurezas, o grau de maturação e a contaminação de aflatoxina. A secagem é importante, pois é o PCC onde a umidade é controlada e consequentemente previne-se a contaminação pelo perigo químico aflatoxina. Durante o armazenamento é realizado o monitoramento da umidade relativa dos armazéns e da umidade dos grãos, se atingir índice superior a $11 \%$ de umidade e aflatoxina superior a 20 ppb os lotes são enviados para o processo de óleo. Nas análises dos lotes pode-se observar que a umidade dos grãos variou de 60 a $6 \%$ do arranquio até os seis meses de armazenamento, sendo que a contaminação fúngica também diminuiu de 1 x 108 para 2 x 105 UFC/g de amendoim. Pode-se concluir que os controles realizados durante toda a cadeia produtiva é importante para a obtenção e amendoins seguros e só é possível com o comprometimento de todos.

Palavras-Chave: Amendoim, APPCC, Contaminação fúngica, Aflatoxinas Agência de Fomento: 